\title{
SOME PROPERTIES OF RAT LIVER MITOCHONDRIAL RNA POLYMERASE*
}

\author{
Christopher J. CHETSANGA, Jay I. NOVETSKY and Michael J. DIMINO $\dagger$ \\ Laboratory of Molecular Biology, Department of Natural Sciences, The University of Michigan, \\ Dearborn, Michigan, USA, 48128, \\ $\dagger$ Department of Research, Sinai Hospital of Detroit, Detroit, Michigan 48235
}

(Received July 21, 1976)

\section{Summary}

A rapid method suitable for purifying large amounts of mitochondria from rat liver using isopycnic zonal centrifugation is described. The RNA polymerase isolated from the purified mitochrondria was found associated with one peak when resolved by DEAE Sephadex chromatography. The enzyme was next fractionated on a phosphocellulose column followed by glycerol gradient centrifugation. A 600 -fold purification was achieved when the enzyme was finally filtered through agarose gel. This final enzyme fraction consisted of one polypeptide chain as shown by polyacrylamide gel electrophoresis profiles. The enzyme has a greater preference for poly $[\mathrm{d}(\mathrm{A}-\mathrm{T})]$ templates than for rat liver mitochondrial DNA. Inhibition of the enzyme activity required high concentrations of the inhibitors. The resistance of the enzyme to $\alpha$-amanitin indicated that there was no contamination from nuclear RNA polymerase II. The conclusion is drawn that the mitochondrial RNA polymerase activity is associated with a single polypeptide.

\footnotetext{
* This work was supported in part by Institutional Grant IN-4ON to the University of Michigan from the American Cancer Society, Grant 360133 from the Rackham School of Graduate Studies and Grant 121010 from the Institute of Science and Technology of the University of Michigan, Grant 340879 from the Michigan Heart Association, and Grants AMO5474 and RRO5641 from the National Institutes of Health.
}

\section{Introduction}

The biogenetic autonomy of mitochondria has been well documented ${ }^{1,2}$ and excellently reviewed recently ${ }^{3.4}$. The transcription of the mitochondrial genome by endogenous RNA polymerase has been reported in studies with both lysed and intact mitochondria ${ }^{5-7}$. Although mitochondrial RNA polymerases from rat liver and yeast have not yet been fully characterized, those from Xenopus laevis ${ }^{8}$ and Neurospora crass ${ }^{9}$ have been better characterized. Conflicting results have been reported on the rifampicin sensitivity of mitochondrial RNA polymerase ${ }^{10-12}$.

The present paper reports the results of our attempts to answer questions concerning some properties of mitochondrial RNA polymerase. Some of the questions relate to the conflicting reports with regard to the enzyme's sensitivity to rifampicin ${ }^{10,11}$ and to its reported partial inhibition by $\alpha$-amanitin ${ }^{13}$ which is known to inhibit specifically eucaryotic nuclear RNA polymerase $\mathrm{II}^{14-16}$. We report here a $30 \%$ inhibition of the RNA polymerase in intact mitochondria and a $70 \%$ inhibition of purified mitochondrial RNA polymerase by a high concentration of rifampicin. The enzyme from well purified mitochondria is insensitive to $\alpha$ amanitin; this evidence suggests that the varying degrees of the reported inhibition of mitochondrial RNA polymerase by $\alpha$-amanitin ${ }^{7,13}$ may be due to contamination by nuclear RNA polymerase II. 


\section{Materials and Methods}

\section{Materials}

Ribonucleoside triphosphates (ATP, CTP, GTP, and UTP), dithiothreitol, 2-mercaptoethanol, calf thymus DNA yeast RNA, Tris (hydroxymethyl) aminomethane, and bovine serum albumin were obtained from Sigma. $\left[{ }^{3} \mathrm{H}\right]$ UTP was from ICN (Irvine, Calif.) while $\alpha$-amanitin was kindly provided by Prof. T. Wieland of Max Planck Institute (Germany). Rifampicin was from Ciba, and Rose Bengal from Fisher. Cytochrome C and ovalbumin were obtained from

Schwarz/Mann Research. Rats were obtained from Spartan Research Animals, Inc., Haslett, Michigan.

\section{Methods}

\section{Purifiaction of mitochondria}

For each experiment three male rats each weighting $150-200 \mathrm{~g}$ were starved overnight and killed by decapitation. All of the following operations were carried out at $0-4^{\circ}$. The livers were removed and washed with several changes of chilled $8.5 \%(\mathrm{w} / \mathrm{w})$ sucrose; this solution and the other sucrose solutions used below were titrated to $\mathrm{pH} 7.4$ with $0.1 \mathrm{~N} \mathrm{KOH}$. The $8.5 \%$ sucrose solution was used in all of the following steps until the zonal centrifugation step. The livers were minced with scissors and rinsed with three changes of sucrose; 20 volumes of sucrose were used for homogenizing the minced livers by means of a Polytron head (Model BEW-10) placed on a Waring blender. The Polytron head was activated for two discountinuous $5 \mathrm{~s}$ periods at high speed, separated by a 1 min interval. The crude homogenate was centrifuged twice at $1000 \times \mathrm{g}$ (GSA rotor, Dupont-Sorvall, Inc.) for $10 \mathrm{~min}$ after which the supernatant was subsequently spun at $6000 \times \mathrm{g}$ for $10 \mathrm{~min}$ and the surface of the resulting pellet rinsed with $8.5 \%$ sucrose. The pellet was resuspended in sucrose and centrifuged two more times with the final pellet (pre-zonal mitochondria) being resuspended in $10 \mathrm{ml}$ of $8.5 \%$ sucrose and further purified by isopycnic zonal centrifugation.

Using a large capacity Beckman model 141 gradient maker, we introduced the following solutions into the rim line of a Ti-14 zonal rotor (Beckman Instruments): (a) an intitial discontinuous gradient consisting of $50 \mathrm{ml}$ each of $12 \%$ (w/w) and $32 \%$ sucrose solutions; (b) a $400 \mathrm{ml}$ continuous shallow linear gradient, ranging from 35 to $47 \%$ sucrose; and (c) a $90 \mathrm{ml}$ cushion of $50 \%$ sucrose. The mitochondrial sample was introduced into the rotor through the core line followed by a $50 \mathrm{ml}$ overlay of $6.5 \%$ sucrose, after which the rotor was spun at $25,000 \mathrm{rpm}$ for $45 \mathrm{~min}$ to approximate an $\omega^{2} \mathrm{t}$ value of $1.9 \times 10^{10}$. At the end of the run, the rotor was unloaded and 26 fractions of $25 \mathrm{ml}$ each collected. After preliminary assays for succinoxidase activity, the fractions containing the postzonal mitochondria were each diluted with $15 \mathrm{ml}$ of double distilled water, and centrifuged at $7500 \times \mathrm{g}$ for $15 \mathrm{~min}$. The resulting pellets were resuspended in $8.5 \%$ sucrose, pooled, and repelleted at $6000 \times \mathrm{g}$ for $10 \mathrm{~min}$. The final pellet was then resuspended in a convenient volume of $0.1 \mathrm{~m}$ Tris-HCl, $\mathrm{pH}$ 7.4. The entire isolation procedure took about $3 \frac{1}{2} \mathrm{hr}$ to complete, giving yields of about 2-3 mg mitochondrial protein per $g$ of liver (wet weight).

\section{Characterization of mitochondria}

Gradient concentrations of sucrose were determined from the refractive index of each fraction as measured with an Abbe refractometer. Succinoxidase activity, a marker for intact mitochondria, was determined polarographically in a $1.1 \mathrm{ml}$ reaction mixture containing $2.7 \mathrm{~mm}$ succinate, $0.225 \mathrm{~m}$ mannitol, $7 \mathrm{~mm}$ sucrose, $1.0 \mathrm{~mm}$ EDTA, and $10 \mathrm{~mm} \mathrm{KH}_{2} \mathrm{PO}_{4}, \mathrm{pH} 7.4$. The polarographic measurements were made in a $25^{\circ}$ temperature-controlled chamber by means of an oxygen electrode (Yellow Springs Instruments Co.). Oxygen uptake was linear for at least $5 \mathrm{~min}$.

\section{Bacterial contamination}

Purified mitochondria were checked for bacterial contamination by plating an aliquot of each preparation on nutrient-agar plates and incubating at $37^{\circ}$ for $24-48 \mathrm{hr}$. The colonies formed were counted with a colony counter to determine the number of bacteria in the mitochondrial preparation.

\section{Chemical analysis}

RNA concentration in the zonal centrifugation fractions was determined both by the method of COOPER et al. ${ }^{17}$ and the orcinol method of DISCHE ${ }^{18}$ using yeast RNA as a standard. DNA was measured by the diphenylamine method of 
BuRTON $^{19}$ with calf thymus DNA as a standard. Protein was measured by the method of LowRY et al. $^{20}$ with bovine serum albumin as a standard.

\section{Assay for RNA synthesis}

The $0.25 \mathrm{ml}$ reaction mixture was composed of $10 \mu$ moles of Tris- $\mathrm{HCl}, \mathrm{pH} 7.9,1 \mu$ mole $\mathrm{MgCl}_{2}$, $0.25 \mu$ mole $\mathrm{MnCl}_{2}, 3 \mu$ moles 2-mercaptoethanol, $0.1 \mu$ mole each of ATP, CTP, GTP, and $\left[{ }^{3} \mathrm{H}\right] \mathrm{UTP}$ $\left(1.2 \times 10^{6} \mathrm{cpm} / \mu\right.$ mole $), 0.25 \mathrm{M} \mathrm{KCl}$ in some cases, calf thymus DNA or mitochondrial DNA (mtDNA), and mitochondrial protein. The level of purification of the enzyme used in the different experiments will be indicated in the appropriate legends.Unless stated otherwise, no DNA template was added to reaction mixtures containing either intact or sonicated mitochondria. The ingredients were mixed in tubes immersed in an ice-bath and incubated at $37^{\circ}$ for the appropriate time periods. The reaction was stopped by the addition of $0.4 \mathrm{ml}$ of cold $50 \% \mathrm{Cl}_{3} \mathrm{CCOOH}$ containing $0.1 \mathrm{M}$ sodium pyrophosphate, and chilled for $10 \mathrm{~min}$ followed by addition of $5 \mathrm{ml}$ of chilled $5 \% \mathrm{Cl}_{3} \mathrm{CCOOH}$. The precipitates were collected on Millipore filters, dried, and counted in a Beckman LS-100 liquid scintillation spectrometer.

\section{Polyacrylamide gel electrophoresis}

$50 \mu \mathrm{g}$ each of material from the DEAE Sephadex column and the Bio-Gel A-1.5 m column was electrophoresed on sodium dodecyl sulfate (SDS) gels according to the method of WeBer and Osborn ${ }^{21}$. Cytochrome $\mathrm{C}$ (mol wt 13,400), ovalbumin (mol wt 43,000) and bovine serum albumin (mol wt 66,000) were used as standard molecular weight markers. After staining and destaining the gels scanned on a Gilford 22 gel scanner at $550 \mathrm{~nm}$.

\section{Experimental and Discussion}

\section{Mitochondria purified by isopycnic zonal cen- trifugation}

A high degree of mitochondrial purity is achieved if the initial differential centrifugation is followed by isopycnic zonal centrifugation. The criterion of mitochondrial purity is the extent to which they are free of bacterial contamination $^{5}$, nuclear contaminants as well as
Table 1. Succinoxidase specific activity and nucleic acid specific concentrations in mitochondria purified to varying degrees. Procedures for isolating mitochondria and assaying succinoxidase activity are as described in "Methods". Values shown for mitochondria resolved by isopycnic zonal centrifugation are for pooled fractions 16-18, and are based on two determinations

\begin{tabular}{|c|c|c|}
\hline \multirow[t]{2}{*}{ Parameter measured } & \multicolumn{2}{|c|}{$\begin{array}{c}\text { Stage of mitochondrial } \\
\text { purification }\end{array}$} \\
\hline & $\begin{array}{l}\text { Differential } \\
\text { centrifugation }\end{array}$ & $\begin{array}{l}\text { Differential } \\
\text { isopycnic zonal } \\
\text { centrifugation }\end{array}$ \\
\hline $\begin{array}{l}\text { Succinoxidase activity } \\
\text { ( } \mu \mathrm{g} \text { A } 0 / \mathrm{h} / \mathrm{mg} \text { protein) }\end{array}$ & 1.6 & 2.0 \\
\hline RNA ( $\mu g / m g$ protein) & 18 & 7 \\
\hline DNA ( $\mu g / m g$ protein) & 6 & 2 \\
\hline
\end{tabular}

cytoplasmic contaminants, especially microsomal material $^{22}$. Our average bacterial colony count of $10^{3}$ per $\mathrm{mg}$ of mitochondrial protein is ten times lower than those reported by other work$\mathrm{ers}^{5,17}$. The results summarized in Table 1 show that the mitochondrial samples purified by differential centrifugation alone had lower succinoxidase specific activity but 2 to 3 times more RNA and DNA per mg protein than did mitochondria purified by subsequent zonal centrifugation.

In Figure 1 it can be readily observed that part of the RNA in the mitochondrial preparation obtained by differential centrifugation is recovered in the material peaking at fraction 8 of the zonal centrifugation. Mitochondrial RNA polymerase on the other hand is recovered in

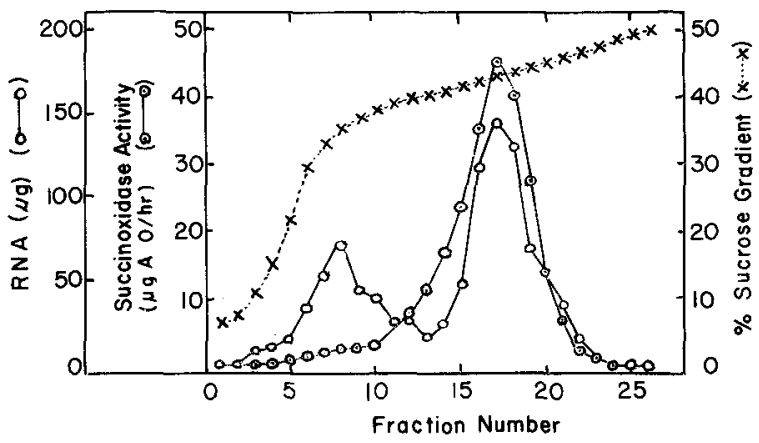

Fig. 1. Distributions of succinoxidase activity and RNA in mitochondrial samples prepared by differential centrifugation and followed by isopycnic zonal centrifugation for 45 min at $25,000 \mathrm{rpm}\left(\omega^{2} t=1.9 \times 10^{10} ; \mathrm{Ti}-14\right.$ rotor, Beckman $)$. Twenty-six fractions $(25 \mathrm{ml}$ each) were collected, diluted with $15 \mathrm{ml}$ of water and sedimented at $7500 \mathrm{~g}$ for $15 \mathrm{~min}$. The pellets were resuspended in $8.5 \%$ sucrose and assayed for succinoxidase activity $(\odot)$, RNA content $(O)$, and sucrose gradient density $(X)$. 


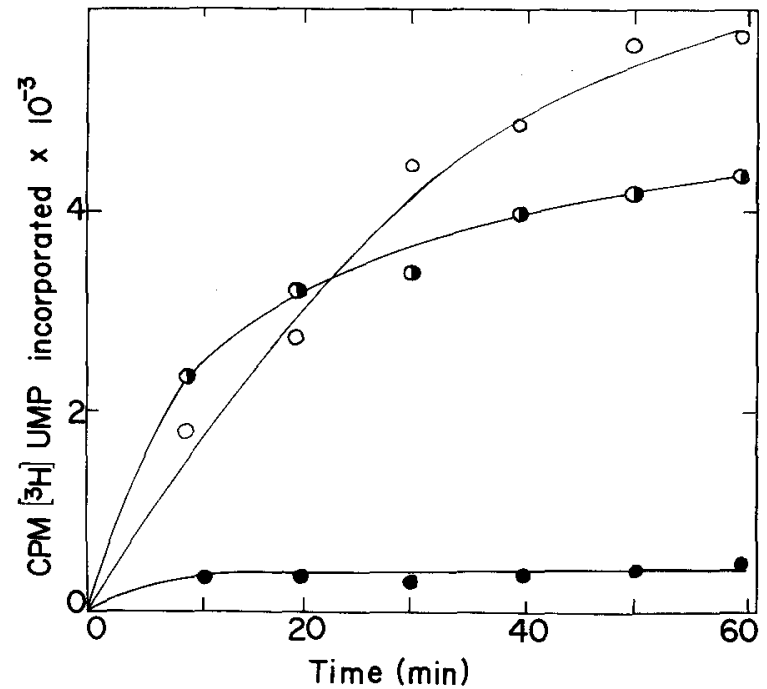

Fig. 2. Kinetics of RNA sythesis directed by intact and lysed mitochondria. A sample mitochondria in $10 \%$ glycerol, $5 \mathrm{~mm}$ Tris- $\mathrm{HCl}$, pH 8.0, was sonicated with the standard tip and centrifuged at $10,000 \mathrm{rpm}$ (SS-34 rotor) for $30 \mathrm{~min}$. The supernatant $(2.5 \mathrm{mg}$ protein, $)$ and the resuspended pellet $(2.5 \mathrm{mg}$ protein, $)$ were assayed for ability to support RNA synthesis; the reaction with intact mitochondria (2.5 $\mathrm{mg}$ protein, $O$ ) was also measured as described under "Methods."

the second peak (fractions 15-20). This is also the peak in which succinoxidase activity is at a maximum level.

\section{Endogenous RNA polymerase activity in mitochondria}

Figure 2 shows that when mitochondria are sonicated with a standard tip and centrifuged at $10,000 \mathrm{rpm}$ for $30 \mathrm{~min}$, enzyme activity is recovered in the supernatant with hardly any activity in the pelleted material. The reaction with intact mitochondria shows slower kinetics than the reactions with sonicated mitochondria during the first $10 \mathrm{~min}$ of incubation; however, with longer incubation time periods, intact mitochondria showed greater transcription activity suggesting that the earlier reduced rate was due to the slow entrance of nucleoside triphosphates into the mitochondria. This observation makes it essential that the transcription assays with intact mitochondria be for incubation periods of $15 \mathrm{~min}$. The enzyme in intact mitochondria requires up to $10^{-3} \mathrm{M}$ rifampicin to inhibit $30 \%$ of its activity; the mitochondrial membrane may act as a permeability barrier that reduces the rate of entry of rifampicin into mitochondria.
Solubilization of mitochondrial RNA polymerase Purified mitochondria ( $420 \mathrm{mg}$ protein) in $10 \mathrm{ml}$ of a solution of $0.05 \mathrm{~m}$ Tris, $\mathrm{pH} 7.9,10 \%$ glycerol, $5 \mathrm{~mm} \mathrm{MgCl}_{2}$. 0.1 mM EDTA and $0.15 \mathrm{~mm}$ dithiothreitol (TGMED buffer) were sonicated for $1 \mathrm{~min}$ with the standard tip of a Branson sonifier (S-75, Heat Sysyems U1trasonics, Inc.) at 24 watts in an ice-bath. Use of the microtip of this sonifier was abandoned when it was found to destroy some of the enzyme activity. The sonicated mitochondria preparation (fraction I) was adjusted to $0.1 \mathrm{M}$ $\left(\mathrm{NH}_{4}\right)_{2} \mathrm{SO}_{4}$ and stirred for $30 \mathrm{~min}$ in an icebath. This treatment was found to enhance the solubilization of the enzyme, as evidenced by the reduction of enzyme activity in the pellet upon subsequent centrifugation at 20,000 rpm (SW 50.1 rotor) for $90 \mathrm{~min}$. The supernatant (fraction II) was recentrifuged at $40,000 \mathrm{rpm}$ for $2 \mathrm{hr}$ to remove more insoluble materials. The supernatant was brought to $60 \%$ saturation with solid $\left(\mathrm{NH}_{4}\right)_{2} \mathrm{SO}_{4}$. After centrifugation at $50,000 \mathrm{rpm}$ (rotor SW 50.1) for $75 \mathrm{~min}$ the pellet was dissolved in $0.05 \mathrm{M}\left(\mathrm{NH}_{4}\right)_{2} \mathrm{SO}_{4}$ made in TGMED buffer, and dialyzed against 100 volumes of the same buffer for 6-12 hr.

\section{DEAE sephadex chromatography}

After ammonium sulfate precipitation and dialysis against $0.05 \mathrm{M}\left(\mathrm{NH}_{4}\right)_{2} \mathrm{SO}_{4}$ in TGMED buffer, the enzyme preparation was fractionated on a DEAE Sephadex (A-25) column (1X $20 \mathrm{~cm})$ pre-equilibrated with $0.05 \mathrm{M}\left(\mathrm{NH}_{4}\right)_{2} \mathrm{SO}_{4}$ in TGMED at $4^{\circ}$. The column was washed with two bed volumes of the loading buffer. The enzyme was eluted with a linear gradient of $0.05 \mathrm{M}-0.5 \mathrm{M}\left(\mathrm{NH}_{4}\right)_{2} \mathrm{SO}_{4}$ in TGMED buffer. One $\mathrm{ml}$ fractions were collected and assayed for enzyme activity. The elution profile showed a small broad peak without enzyme activity as well as a major peak which contained the RNA polymerase activity (Fig. 3). This major protein peak was eluted with $0.27 \mathrm{M}\left(\mathrm{NH}_{4}\right)_{2} \mathrm{SO}_{4}$. Colorimetric determination ${ }^{20}$ showed that the two peaks both contained protein. The enzyme activity in the major peak was collected as fraction III RNA polymerase.

\section{Phosphocellulose chromatography}

The enzyme was further fractionated on a phosphocellulose column by the method of BuRGESs $^{23}$. Two protein peaks were resolved 


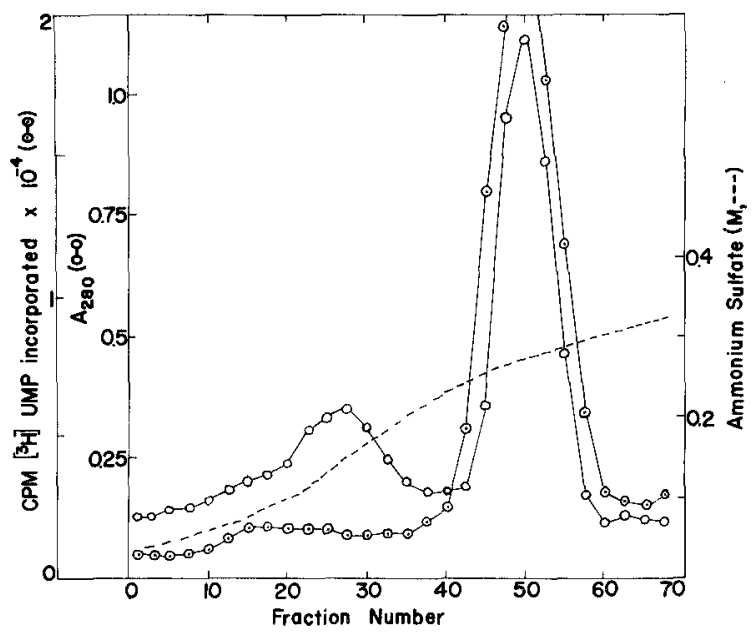

Fig. 3. Elution of mitochondrial RNA polymerase from a DEAE Sephadex column. The supernatant from sonicated mitochondria (203 $\mathrm{mg}$ protein) was dialyzed for $12 \mathrm{hr}$ against $0.1 \mathrm{M}\left(\mathrm{NH}_{4}\right)_{2} \mathrm{SO}_{4}$ made in TGMED buffer. The sample was loaded onto the column and eluted with a linear gradient of $0.1-0.5 \mathrm{M}\left(\mathrm{NH}_{4}\right)_{2} \mathrm{SO}_{4}$ in TGMED buffer. $1.0 \mathrm{ml}$ fractions were collected and assayed for enzyme activity. Fractions $45-55$ were pooled for further analysis. The molarity of $\left(\mathrm{NH}_{4}\right)_{2} \mathrm{SO}_{4}$ in each fraction was measured with conductivity meter. $\mathrm{A}_{280}(\mathrm{O})$, cpm of $\left[{ }^{3} \mathrm{H}\right] \mathrm{UMP}$ incorporated $(\odot)$, and concentration of $\left(\mathrm{NH}_{4}\right)_{2} \mathrm{SO}_{4}(---, \mathrm{M})$.

(Fig. 4). The peak around fractions 10-22 had no enzyme activity; it was fractions $34-46$ that contained the fraction IV enzyme activity. These fractions were pooled for further processing in glycerol gradients.

\section{Glycerol gradient}

The enzyme was further purified by centrifugation in $10-30 \%$ glycerol gradients (SW 50.1 rotor). The TGMED buffer used for making the glycerol gradients contained $0.25 \mathrm{M} \mathrm{KCl}$. The gradients were centrifuged at $30,000 \mathrm{rpm}$ for $12 \mathrm{hr}$ at $4^{\circ}$. Fractions $(0.12 \mathrm{ml})$ were collected and assayed for enzyme activity (fraction V). Figure 5 shows the sedimentation profile of the enzyme. It can be observed that the activity banded in a single region of the gradient encompassing fractions $16-21$. There was no enzyme activity in fractions $1-15$ on the heavier side of the glycerol gradient.

\section{Bio-gel chromatography}

Fraction V enzyme from glycerol gradients was finally purified by gel filtration on a Bio-Gel A-1.5 m column. A solution of $0.25 \mathrm{M} \mathrm{KCl}$ in TGMED buffer was used for eluting the enzyme

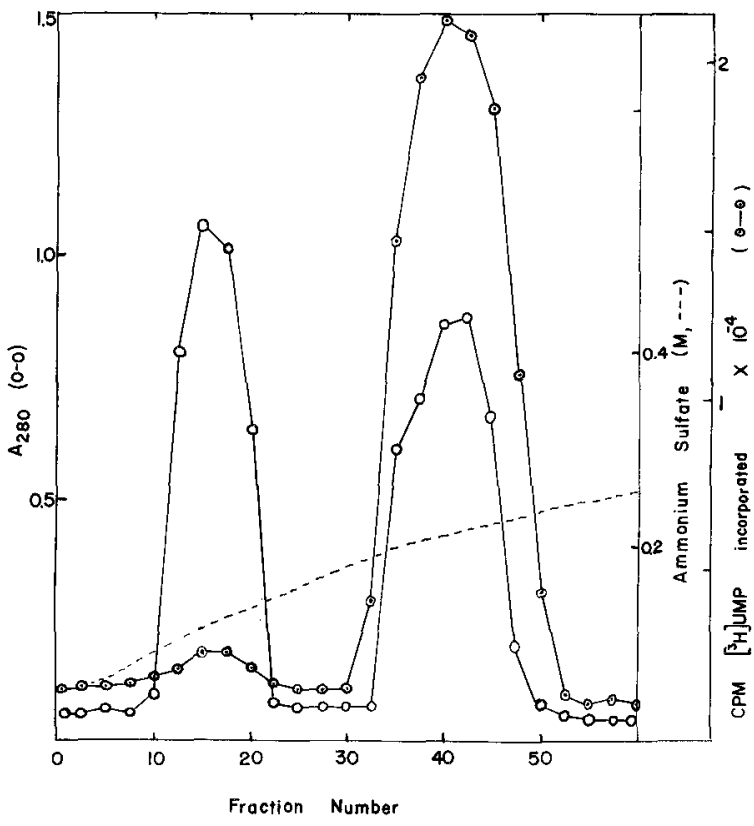

Fig. 4. Elution profile of mitochondrial RNA polymerase from a phosphocellulose column. The enzyme $(4.8 \mathrm{mg}$ protein) from the DEAE Sephadex (A-25) column was applied to a phosphocellulose column $(1.5 \times 10 \mathrm{~cm})$ preequilibrated with $0.05 \mathrm{M}\left(\mathrm{NH}_{4}\right)_{2} \mathrm{SO}_{4}$ TGMED and eluted with a linear gradient of $0.1 \mathrm{M}-0.4 \mathrm{M}\left(\mathrm{NH}_{4}\right)_{2} \mathrm{SO}_{4}$. Fractions of $0.5 \mathrm{ml}$ each were collected and assayed; fractions 35-46 were pooled. $\mathbf{A}_{280}(\mathcal{O})$, cpm of $\left[{ }^{3} \mathrm{H}\right] \mathrm{UMP}$ incorporated $(\odot)$, and linear gradient of $\left(\mathrm{NH}_{4}\right)_{2} \mathrm{SO}_{4}(---)$.

from the column. In Figure 6 the sedimentation profile of the enzyme shows two peaks. The first peak (fractions 15-20) did not contain enzyme activity which was found in the second peak composed of fractions 26-33. The material in the second peak was used as fraction VI mitochondrial RNA polymerases in the experiments reported below.

Table 2 summarizes steps used in purifying rat liver mitochondrial RNA polymerase. The overall process of purification involved the utilization of four fractionation steps. The subsequent chromatography of material from the DEAE Sephadex column on a phosphocellulose column led to about 2.9-fold further purification. The chromatography on an agarose gel column removed a protein component from the enzyme activity which had not been separated by the glycerol gradient. Agarose gel filtration resulted in an over-all 600-fold purification of the enzyme.

Table 3 shows the requirements for the transcription reaction catalyzed by fraction VI 


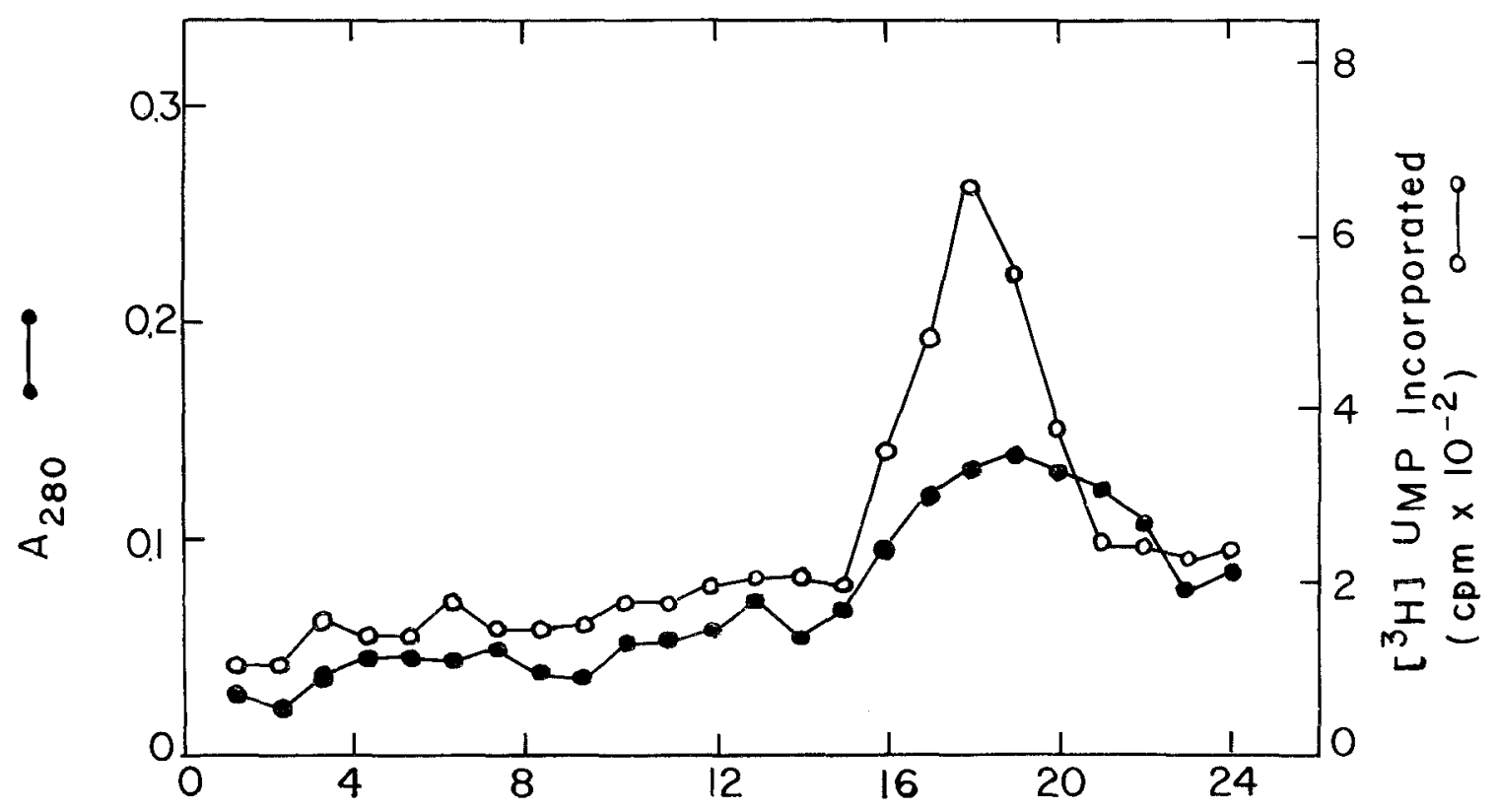

Fraction Number

Fig. 5. Glycerol gradient sedimentation of rat liver mitochondrial RNA polymerase. Protein from the peak material from the phosphocellulose column was layered over a 10-30\% glycerol gradient prepared in $0.25 \mathrm{M} \mathrm{KCl}$, TGMED buffer, and centrifuged at $50,000 \mathrm{rpm}$ for $2 \frac{1}{2} \mathrm{hr}$ in the SW 50.1 rotor. Fractions $(0.2 \mathrm{ml})$ were collected and assayed. $\mathrm{A}_{280}(\mathbf{O})$, and $\mathrm{cpm}$ of $\left[{ }^{3} \mathrm{H}\right] \mathrm{UMP}$ incorporated $(\mathrm{O})$.

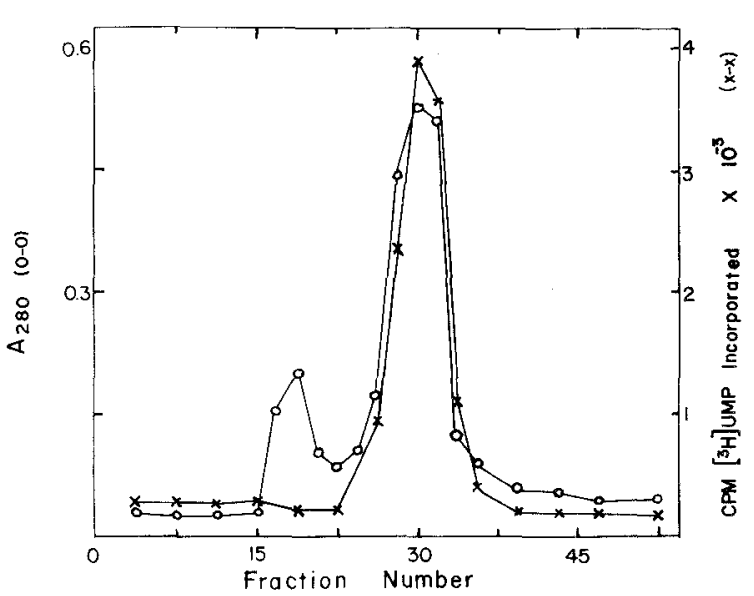

Fig. 6. Profile of filtration of mitochondrial RNA polymerase through a Bio-gel A-1.5 m agarose column. Protein recovered from glycerol gradients was passed through an agarose gel column $(1.2 \times 15 \mathrm{~cm})$ and eluted with $0.25 \mathrm{M}$ $\mathrm{KCl}, \mathrm{TGMED}$ buffer solution. Fractions of $0.3 \mathrm{ml}$ each were collected and assayed. Fractions 28-32 were pooled and used as fraction VI in transcription assays. $\mathrm{A}_{280}(\mathrm{O})$, and cpm of $\left[{ }^{3} \mathrm{H}\right]$ UMP incorporated $(x)$. mitochondrial RNA polymerase. The reaction requires a DNA template, the nucleoside triphosphate substrates and $\mathrm{Mg}^{++}$. The absence of $\mathrm{Mn}^{++}$reduces the reaction by only $20 \%$. The presence of $0.25 \mathrm{M} \mathrm{KCl}$ has a $30 \%$ inhibitory effect on the activity of the enzyme. This is unlike what has been observed with bacterial RNA polymerase reactions in which $0.25 \mathrm{M} \mathrm{KCl}$

Tabie 2. Purification of mitochondrial RNA polymerase. The fractions of enzyme recovered at different stages of purification were characterized on the basis of yield of protein and level of enzyme activity in the appropriate fraction, measured by incubating reaction mixtures at $37^{\circ}$ for $10 \mathrm{~min}$

\begin{tabular}{|c|c|c|c|c|c|}
\hline & Fraction & $\begin{array}{c}\text { Total } \\
\text { protein } \\
(\mathrm{mg})\end{array}$ & $\begin{array}{l}\text { Units\% } \\
\left(\times 10^{-3}\right)\end{array}$ & $\begin{array}{l}\text { Specific } \\
\text { activity } \\
\text { (units/mg) }\end{array}$ & $\begin{array}{l}\text { Fold } \\
\text { purifi- } \\
\text { cation }\end{array}$ \\
\hline 1. & $\begin{array}{l}\text { Sonicated whole } \\
\text { mitochondria }\end{array}$ & 420 & 5.1 & 12 & 1 \\
\hline 11. & $\begin{array}{l}\text { Mitochondría } \\
\text { supernatant }\end{array}$ & 260 & 26.6 & 102 & 36 \\
\hline I1।. & $\begin{array}{l}\text { DEAE Sephadex } \\
\text { enzyme }\end{array}$ & 6.2 & 8.8 & 1420 & 118 \\
\hline IV. & $\begin{array}{l}\text { Phosphocellulose } \\
\text { enzyme }\end{array}$ & 2.4 & 10 & 4130 & 343 \\
\hline v. & $\begin{array}{l}\text { Giycerol gradient } \\
\text { enzyme }\end{array}$ & 1.7 & 9.8 & 5800 & 496 \\
\hline VI. & $\begin{array}{l}\text { Bio-Gel } A-1.5 \mathrm{~m} \\
\text { enzyme }\end{array}$ & 1.0 & 7.4 & 7400 & 620 \\
\hline
\end{tabular}

* A unit of enzyme activity is the amount catalyzing the incorporation of one pM of [ $\left.{ }^{3} \mathrm{H}\right]$ UTP into RNA in $10 \mathrm{~min}$ at $37^{\circ}$ 
Table 3. Requirements for the mitochondrial RNA polymerase reaction.

Fraction VI enzyme was used in the reaction system described in

Materials and Methods supplemented

with bovine serum albumin. Template used was rat mitochondrial DNA.

Data based on 5 experiments

\section{Experimental conditions \% activity}

\begin{tabular}{lr}
\hline Complete system & 100 \\
-template & 10 \\
-Mg++ & 42 \\
-Mn++ & 80 \\
-ATP, CTP, GTP & 4 \\
-mercaptoethanol & 88 \\
+0.25 M KCl & 70 \\
\hline
\end{tabular}

stimulates the rate of RNA synthesis by promoting a reinitiation of new chains ${ }^{24,25}$. This sensitivity to $0.25 \mathrm{M} \mathrm{KCl}$ is further evidence of the absence of bacterial contamination in our mitochondrial preparations. ReID and PARSONS ${ }^{5}$ also found $0.2 \mathrm{M}\left(\mathrm{NH}_{4}\right)_{2} \mathrm{SO}_{4}$ to be inhibitory to the activity of this mitochondrial enzyme.

\section{Polyacrylamide gel electrophoresis}

To determine the degree of final purity achieved by chromatography of the enzyme on the agarose gel column we used analytical SDS polyacrylamide gel electrophoresis to compare the enzyme from the DEAE Sephadex column with that purified through the agarose gel step (Fig. 7). The electrophoretic profiles show that fraction III is composed of several protein species which give multiple bands whereas fraction VI migrates in a single band under these electrophoresis conditions. Fraction III is thus quite heterogeneous when compared with fraction VI with displays electrophoretic homogeneity. This migration of the agarose gel enzyme in one band indicates that rat liver mitochondrial RNA polymerase consists of one activity. The distance migrated by fraction VI on the gel corresponds to that of a protein whose molecular weight is about 62,000 65,000 . KunTzEL and SCHAFER ${ }^{9}$ have reported that the mitochondrial RNA polymerase from $N$. crassa also consists of one polypeptide chain of molecular weight 64,000. MUKERJEE and GOLDFEDER $^{13}$ purified rat liver mitochondrial RNA polmerase by DEAE Sephadex chromatography and resolved it into a major protein band (66,000 daltons) and a low mobility minor protein band by gel electrophoresis. These molecular weights of the rat liver and $N$. crassa enzymes are higher than the 46,000 reported by WU and DAWID ${ }^{13}$ for the $X$. laevis RNA polymerase. It thus appears that the mitochondrial enzymes from different species are heterogeneous in size.

While MUKERJEE and GOLDFEDER were able to

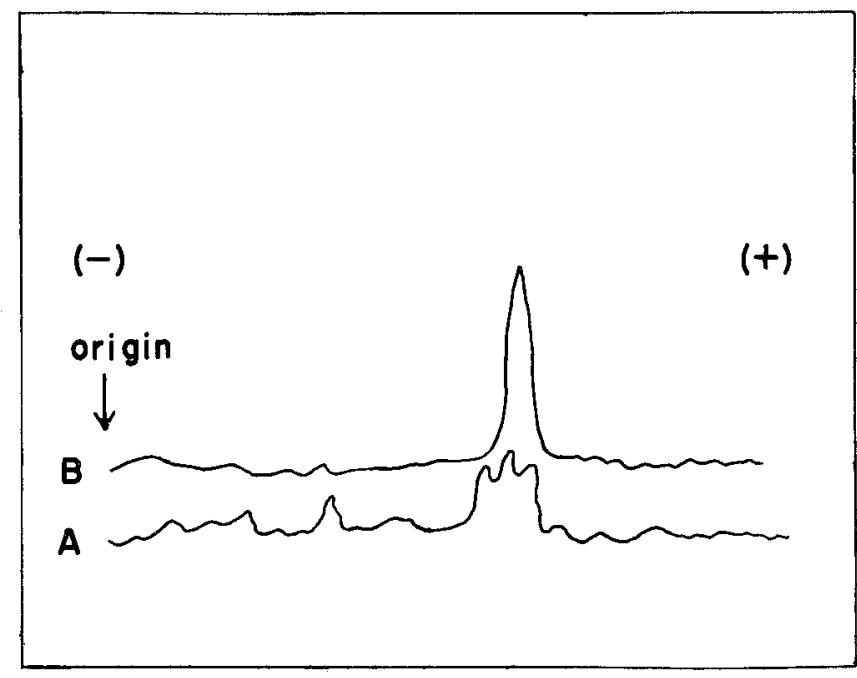

Fig. 7. Densitometric tracings of mitochondrial RNA polymerase on SDS gels. $50 \mu \mathrm{g}$ of enzyme from a DEAE Sephadex (A) and a Bio-gel A-1.5 m (B) column was electrophoresed and stained. After destaining, the gels were scanned at $550 \mathrm{~nm}$ on a Gilford 220 gel scanner. 
resolve the material solubilized from rat liver mitochondria into four peaks; it has been our experience that the number of enzymecontaining peaks from the DEAE-Sephadex column can be reduced to one by the combined use of well purified mitochondria, as well as by the initial $60 \%\left(\mathrm{NH}_{4}\right)_{2} \mathrm{SO}_{4}$ precipitation step from which $90 \%$ of the RNA polymerase activity is recovered. We have found the additional purification steps through the agarose gel step to be essential in order to remove more protein components still present in the enzyme. WU and DAwID ${ }^{8}$ obtained the $X$. laevis mitochondrial enzyme as an electrophoretically homogeneous enzyme after purifying it through the glycerol gradient step and did not have to use gel filtration.

\section{Effect of Rose Bengal and rifampicin on mitochondrial RNA polymerase}

Figure 8 shows the effect of Rose Bengal and rifampicin on the activity of RNA polymerase from the agarose gel column. The results show that mitochondrial RNA polymerase is not completely inhibited by concentrations of Rose Bengal up to $10^{-5} \mathrm{M}$. Recently $\mathrm{Wu}$ and $\mathrm{Wu}^{26}$ have shown that Rose Bengal is a potent inhibitor of $E$. coli RNA polymerase and have proposed that the inhibition is either on phosphodiester bond formation during chain propagation or on the translocation of the enzyme along the template. The possibility that the effect of Rose Bengal is on the enzyme itself cannot be ruled out at the present time. Their results showed that $10^{-5} \mathrm{M}$ Rose Bengal completely inhibits the activity of the $E$. coli enzyme when either calf thymus or T7 DNA was used as template. Figure 8 also shows that it takes about $10^{-3} \mathrm{M}$ rifampicin to inhibit this enzyme by about $74 \%$. The rifampicin sensitivity of the enzyme is thus less than that of $E$. coli RNA polymerase which is almost completely inhibited by $4 \times 10^{-5} \mathrm{M}$ rifampicin ${ }^{27}$. Even at these higher concentrations of rifampicin, the activity of mitochondrial RNA polymerase does not seem to be completely inhibited. Wu and DAwID $^{8}$ have made similar observations with mitochondrial RNA polymerase of $X$. laevis. This reduced sensitivity of the mitochondrial enzyme to rifampicin has interesting implications when considered in the light of the hypothesis that mitochondria evolved from pro-

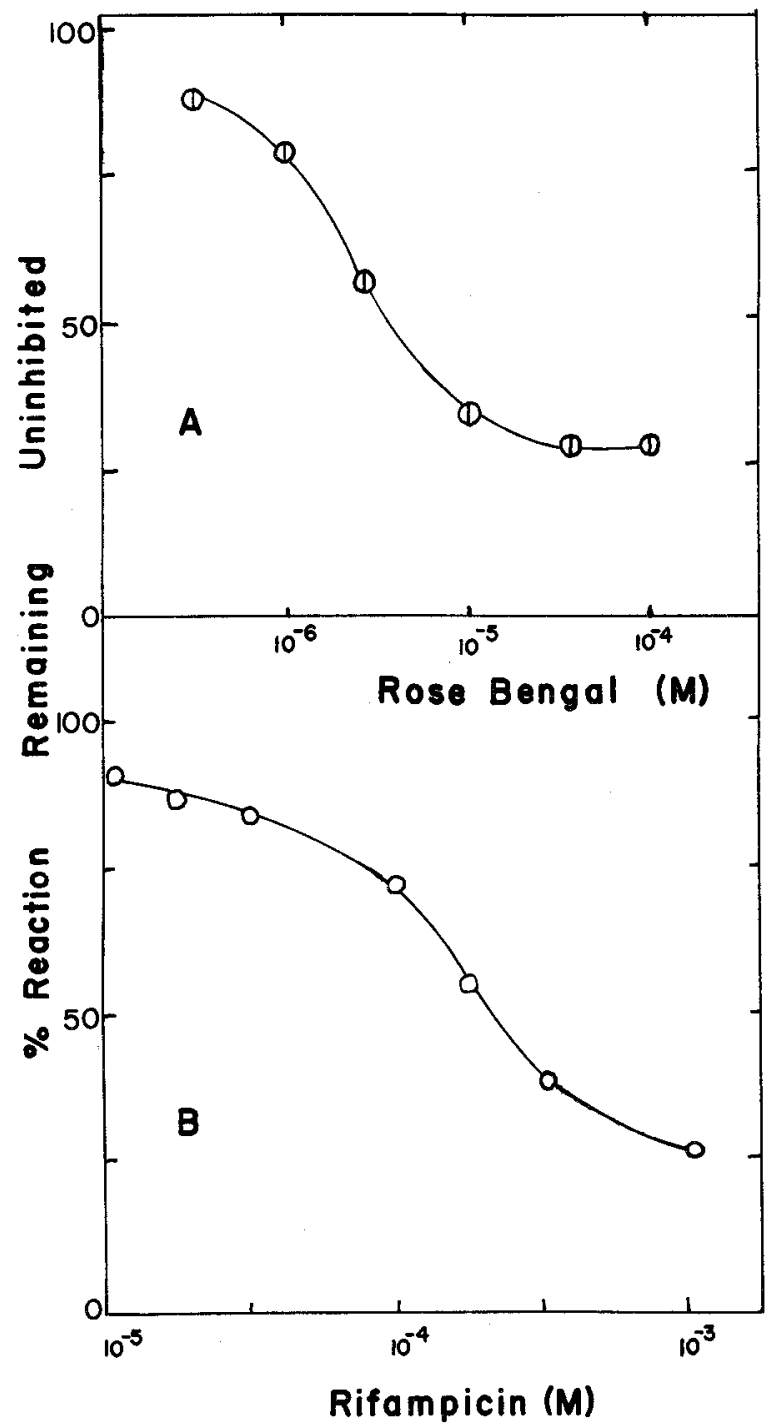

Fig. 8. Inhibition of RNA synthesis by rifampicin and Rose Bengal. The reaction mixtures were incubated for $15 \mathrm{~min}$ at $37^{\circ}$. (A) reactions with varying concentrations of Rose Bengal $(D)$ : $(B)$ reactions with varying amounts of rifampicin (O). In each reaction $2.4 \mu \mathrm{g}$ of fraction VI enzyme and $2.5 \mu \mathrm{g}$ calf thymus DNA.

karyotes ${ }^{4}$. It can be speculated that this considerable resistance to rifampicin exhibited by the enzyme, developed as part of the evolutionary process by which mitochondria adapted to the eukaryotic cell. We found that $\alpha$-amanitin does not inhibit mitochondrial fraction VI RNA polymerase. This observation indicates that our enzyme is not contaminated with nuclear RNA polymerase II.

Poly $[d(A-T)]$ has been reported to be the preferred template for both the $N$. crassa and 


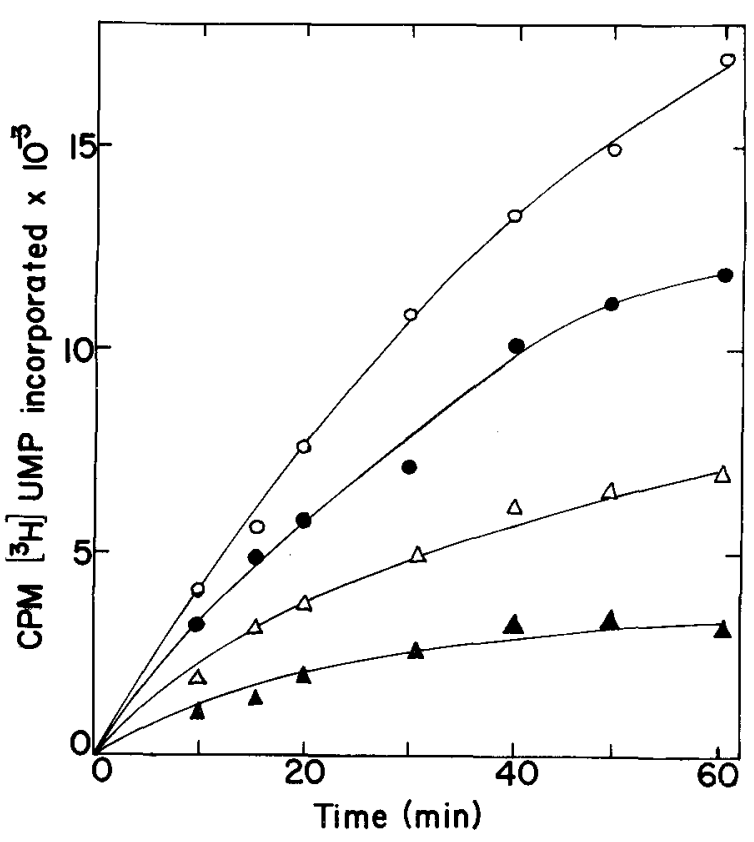

Fig. 9. Kinetics and template preference of the mitochondrial RNA polymerase reaction. Fraction VI enzyme $(2.1 \mu \mathrm{g})$ from an agarose gel column was used in this assay. The time-course of RNA synthesis supported by $2.5 \mu \mathrm{g}$ each of poly $[\mathrm{d}(\mathrm{A}-\mathrm{T})](\mathrm{O})$, mtDNA $(\mathbf{)})$, calf thymus DNA $(\triangle)$, and mtDNA in presence of $10^{-3} \mathrm{M}$ rifampicin $(\boldsymbol{\Delta})$.

the $X$. laevis mitochondrial RNA polymerase ${ }^{8,9}$. We have compared the template preference of rat liver mitochondrial RNA polymerase with respect to mtDNA, calf thymus DNA, and synthetic poly $[d(A-T)]$ templates. Our results show that the rat liver enzyme also prefers the $\mathrm{d}(\mathrm{A}-\mathrm{T})$ copolymer to both mtDNA and calf thymus DNA (Fig. 9). In $10 \mathrm{~min}, 2.1 \mu \mathrm{g}$ of the enzyme catalyzes the incorporation of 3.12 nmoles of UMP with poly [d(A-T)], 2.5 nmoles with mtDNA, and 1.6 nmoles with calf thymus DNA templates. KUNTZEL and SHAFER ${ }^{9}$ reported that the $N$. crassa enzyme $(2 \mu \mathrm{g})$ catalyzes the incorporation of 4 nmoles of UMP in $10 \mathrm{~min}$. These investigators were working with larger amounts of homologous mtDNA in their reactions; it is, therefore, not possible to make a direct comparison of our results with theirs.

Although it has been proposed that the poly $[\mathrm{d}(\mathrm{A}-\mathrm{T})]$ preference of the mitochondrial enzyme may reflect the presence of A-T rich regions in $\mathrm{mtDNA}^{28}$, to our knowledge this inference has not yet been demonstrated experimentally. Figure 9 also shows that in reactions with mtDNA templates, $10^{-3} \mathrm{M}$ rifampicin causes a $70 \%$ inhibition of the activity of the enzyme.

In conclusion we would like to point out that the rapid method of isolating mitochondria described here lends itself well to preparing large amounts of these organelles. The reduced handling time seems to minimize the loss of enzyme activity reported by others ${ }^{29}$. We also found the rat liver enzyme to be quite unstable; the presence of bovine serum albumin helped to stabilize the enzyme. The specific activity of the rat liver RNA polymerase approximates those of the $X$. laevis ${ }^{8}$ and $N$. crassa ${ }^{9}$ enzymes. We found that the specific activity of the enzyme can be reduced more than 10 -fold by freezing and thawing, as well as by prolonged handling during purification. These factors need to be taken into consideration when comparing the properties of mitochondrial RNA polymerases from different species.

\section{References}

1. Arneberg, A. C., Van Bruggen, E. F. J., Flavell, R. A. and Borst, P., 1973. Biochim. Biophys. Acta 380, 276-284.

2. Tibbetts, C. J. B. and Vinograd, J., 1973. J. Biol. Chem. 248, 3380-3385.

3. Ashwell, M. and Work, T. S., 1970. Ann. Rev. Biochim. 39, 251-290.

4. Mahler, H. R., 1973. Mitochondria: Molecular Biology, Genetics and Development, Addison-Wesley Publishing Co., Inc., Reading, Mass.

5. Reid, B. D. and Parsons, P., 1971. Proc. Nat. Acad. Sci. U.S.A. $68,2830-2834$.

6. Suyama, Y. and Eyer, J., 1968. J. Biol. Chem. 243, 320-328.

7. Tsai, M., Michaelis, G. and Griddle, R. S., 1970. Proc. Nat. Acad. Sci. U.S.A. 68, 473-477.

8. Wu, G.-J. and Dawid, I. B., 1972. Biochemistry 11, 3589-3595.

9. Kuntzel, H. and Schafer, K. P., 1971. Nature New Biology 231, 265-269.

10. Wintersberger, E. and Wintersberger, U., 1970. FEBS Lett. 6, 58-60.

11. Gadaleta, M. N., Greco, M. and Saccone, G., 1970. FEBS Lett. 10, 54-56.

12. Gamble, J. G. and McCluer, R. H., 1970. J. Mol. Biol $53,557-562$.

13. Mukerjee, H. and Goldfeder, A., 1973. Biochemistry 12, 5096-5101.

14. Kedinger, C., Gniazdowski, M., Mandel, J. L., Jr., Gissinger, F. and Chambon, P., 1970. Biochem. Biophys. Res. Commun. 38, 165-171.

15. Lindell, T. J., Weinberg, F., Morris, P. W., Roeder, R. G. and Rutter, W. J. 1970. Science 170, 447-449. 
16. Mondal, H., Mondal, R. K. and Biswas, B. B., 1970. Biochem. Biophys. Rew. Commun. 40, 1197-1200.

17. Cooper, W. K., Muramatsu, K. and Wannemacher, R. W., 1968. Biochim. Biophys. Acta 169, 269-271.

18. Dische, Z., 1955. in The Nucleic Acids (Chargaff, E. and Davidson, J. N., eds) Vol. I, pp. 285-305, Academic Press, N.Y.

19. Burton, K., 1956. Biochem. J. 63, 315-323.

20. Lowry, O. H., Rosebrough, N. J., Farr, A. L. and Randall, R. J., 1951. J. Biol. Chem. 193, 265-275.

21. Weber, K. and Osborn, M., 1969. J. Biol. Chem. 244, 4406-4412.

22. O'Brien, T. W. and Kalf, G. F., 1967. J. Biol. Chem. 242, 2172-2179.

23. Burgess, R. R., 1969. J. Biol. Chem. 244, 6160-6167.

24. Maitra, U. and Barash, F., 1969. Proc. Nat. Acad. Sci. U.S.A. 64, 779-786.

25. So, A. G., Davie, E. W., Epstein, R. and Tessieres, A., 1967. Proc. Nat. Acad. Sci. U.S.A. 58, 1739-1746.

26. Wu, F. Y.-H. and Wu, C.-W., 1973. Biochemistry 12, 4343-4348.

27. Bremmer, H., 1970. Cold Spring Harbor Symp. Quant. Biol. 35, 109-119.

28. Bernardi, G., Carnevali, F., Nicolaieff, A., Piperno, G. and Tecce, G., 1968. J. Mol Biol. 37, 493-505.

29. Wintersberger, E., 1973. in Regulation of Transcription and Translation in Eucaryotes (Bautz, E. K. F., Karlson, P. and Kersten, H., eds.) pp. 179-193, Springer-Verlag, N.Y. 